\title{
Pensar a Revolução Soviética no século XXI: Revolução e estratégias identitárias
}

Thinking the Soviet Revolution in the Twenty-first Century: Revolution and Identity Strategies

Penser la Révolution soviétique au XXIème siècle : Révolution et stratégies identitaires

\section{Mário Machaqueiro}

\section{(2) OpenEdition}

\section{Journals}

Edição electrónica

URL: http://journals.openedition.org/rccs/762

DOI: $10.4000 /$ rccs.762

ISSN: 2182-7435

\section{Editora}

Centro de Estudos Sociais da Universidade de Coimbra

Edição impressa

Data de publição: 1 Outubro 2007

Paginação: 139-172

ISSN: 0254-1106

Refêrencia eletrónica

Mário Machaqueiro, "Pensar a Revolução Soviética no século XXI: Revolução e estratégias identitárias », Revista Crítica de Ciências Sociais [Online], 78| 2007, colocado online no dia 01 outubro 2012, criado a 01 maio 2019. URL : http://journals.openedition.org/rccs/762 ; DOI : 10.4000/rccs.762

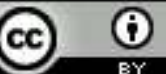




\title{
MÁRIO MACHAQUEIRO
}

\section{Pensar a Revolução Soviética no século XXI: Revolução e estratégias identitárias}

\begin{abstract}
A problemática das identidades sociais tem sido um dos principais veios dos estudos soviéticos e pós-soviéticos, sobretudo desde os anos 9o. Esses trabalhos contribuem para aprofundar a compreensão da Revolução Soviética, ao mesmo tempo que permitem uma articulação com a centralidade das questões identitárias no momento histórico presente. Retomando o espírito desses estudos, mas também de investigações que, entre nós, têm procurado desenvolver uma antropologia geral dos processos identitários, este artigo procura reanalisar a evolução do pensamento de Lénine e do regime bolchevique à luz da inserção identitária ambivalente da Rússia entre a Ásia e a Europa, entre o Oriente e o Ocidente. Para tal, recorre-se ao conceito de "identidade de fronteira", utilizando-o para esclarecer as oscilações que caracterizaram as escolhas estratégicas dos comunistas russos no domínio da geopolítica.
\end{abstract}

\section{A Revolução Soviética e o regresso das identidades}

Uma das portas de entrada para o regresso à Revolução Soviética enquanto objecto de análise sociológica, agora que a poeira parece ter assentado definitivamente sobre o "som e a fúria" que ela suscitou, pode residir no conhecimento que o seu estudo proporciona a respeito das estratégias cognitivas exploradas pelos actores sociais quando confrontados com experiências de transição histórica. Estando essas estratégias profundamente inscritas em processos identitários, os quais constituem o ponto fulcral para onde parecem convergir, neste século XXI, muitas das nossas perplexidades científicas e políticas, a compreensão do modo como tais processos se constelaram, no passado, com outras determinantes das trajectórias históricas só pode encerrar, para nós, ensinamentos produtivos.

A própria evolução recente da historiografia sobre a Revolução Soviética obriga a que a análise dos processos cognitivos desenvolvidos pelos seus protagonistas passe por duas noções basilares: a de identidade e a de construção identitária. Com efeito, a problemática das identidades sociais, nomeadamente das identidades de classe, tem sido um dos principais veios dos estudos soviéticos e pós-soviéticos, sobretudo desde os anos 90 (Fitzpatrick, 1991, 1993; Siegelbaum e Suny, 1994; Melançon e Pate, 2002). 
Sendo assim, e retomando o espírito desses estudos, mas também de trabalhos que, entre nós, têm procurado desenvolver uma antropologia geral dos processos identitários (Bastos, 1995, 2000), defino aqui identidade como uma auto-representação elaborada por sujeitos individuais, mediante a qual estes se atribuem certos traços e rejeitam outros, definindo relações imaginárias de auto-inclusão e de auto-exclusão relativamente a grupos de referência que o sujeito representa como positivos ou negativos. A identidade funciona, portanto, como uma construção estratégica orientada para a preservação, para a protecção e, eventualmente, para a expansão imaginária do sujeito. Neste sentido, convém sempre lembrar que as identidades "colectivas", aquelas cujos traços são partilhados no interior de grupos a um ponto em que as mesmas parecem autonomizar-se em relação aos sujeitos, assentam em processos de integração e de elaboração individualizadas. $\mathrm{O}$ esquecimento deste aparente truísmo tem alimentado muita "metafísica" identitária.

Poderemos interrogar-nos sobre as razões que levam a que a temática da identidade seja tão relevante numa investigação a respeito das produções cognitivas que acompanham os processos de transição social de tipo revolucionário. Segundo creio, essas razões são, pelo menos, três. Em primeiro lugar, porque a identidade enquadra todos os mecanismos de auto-percepção com que o sujeito se interpreta e interpreta o mundo. Ou seja, o modo como ele se posiciona nas representações de identidade condiciona os seus recursos cognitivos. Condiciona, portanto, não apenas a maneira como manipula os saberes, mas a própria esquadria mental que lhes dá forma (a tendência para o dualismo como estratégia cognitiva, por exemplo, pode ser o resultado da projecção de uma certa matriz identitária). Além disso, um outro motivo para privilegiar as representações e as estratégias identitárias como foco de análise tem que ver com o facto de que, ao abordarmos o fenómeno das identidades, somos forçados a reconhecer a centralidade do delírio nas representações sociais e, em particular, nas formas de conhecimento que os sujeitos produzem acerca de si próprios e do mundo. Isto implica entender todo o exercício cognitivo como um exercício essencialmente delirante (projectivo, idealizante, fantasmático, etc.), e implica também perceber que a dinâmica subjacente aos processos sociais não é exactamente compatível com a imagem do ser humano como animal racional, autoconsciente, senhor de si e das suas escolhas, etc. Este aspecto é ilustrado com o predomínio, na Rússia, do familialismo como forma identitária de organizar as relações de poder, quer no plano das diferentes identidades de classe (o campesinato, o operariado e os intelectuais), quer no âmbito dos vários espaços sociais. A predominância do familialismo na mentalidade 
russa mostra como a matriz fantasmática das relações intra-familiares (entre pais e filhos, ou entre adultos e crianças) pode ser manipulada para formatar as relações de poder político (quando, por exemplo, o czar da Rússia é identificado como um "pai da nação", ou quando os dirigentes comunistas, Lénine e Stáline, são representados com o estatuto de "pais dos povos"). Finalmente, o tema da identidade contribui para repensar a conflitualidade social e política na perspectiva dos actores sociais, ao reconduzir essa conflitualidade, as relações e estratégias de poder que lhe são inerentes, à matriz dos conflitos identitários. Tais conflitos resultam, em grande medida, da protecção das diferenças de identidade ou dos projectos de expansão hegemónica de identidades que se querem dominantes. Assim, a atenção aos processos cognitivos articula-se com a compreensão do como as identidades sociais, de classe, de etnia, sexuais, se constituíram enquanto matrizes de percepção ou de interpretação dos fenómenos sociais e políticos.

\section{Rússia, uma "identidade de fronteira"}

A abertura às dimensões mais complexas dos processos identitários, estimulada sobretudo pelos estudos do "pós-colonialismo", enfatizou não apenas a historicidade de tais processos, mas também os efeitos de intermediação, de pluralidade intrínseca e de hibridez na construção social das identidades individuais e colectivas (Bhabha, 1994; Gilroy, 1996; Hall e Gay, 1996; Morley e Chen, 1996). Inspirando-me nessa tradição teórica e nas análises desenvolvidas por Boaventura de Sousa Santos em relação à cultura portuguesa, por ele concebida como "cultura de fronteira" (Santos, 1994: 132-136), proponho-me introduzir aqui a noção de identidade de fronteira, concebida enquanto forma estrutural das representações identitárias dominantes na cultura russa.

Com o termo "identidade de fronteira", designo uma auto-imagem, cultural e socialmente construída, que apresenta dimensões cujo alcance importa elucidar. Antes de mais, nas identidades de fronteira a auto-representação do sujeito é mista e internamente dividida entre modelos de referência que concorrem entre si. O sujeito hesita, ou não é sequer capaz de distinguir com segurança, entre as imagens alternativas que se fundem e se confundem nele. As identidades de fronteira caracterizam-se pela indecidibilidade (Santos, 2002: 44-46, 54), a qual se manifesta sempre que a relação tensional entre imagens alternativas (ou opostas) conduz o sujeito a não poder decidir-se em definitivo por uma em detrimento das suas rivais. A indecidibilidade aparece invariavelmente acompanhada por outro sinal das identidades e dos imaginários "de fronteira": a ambivalência, entendida aqui como a flutuação dos afectos que os sujeitos investem, alternadamente, 
em posições opostas, isto é, como a oscilação do pêndulo afectivo entre umas e outras. Essa oscilação é indecidida e indecidível. Quando uma tal hesitação se cruza com "estruturas profundas" de uma determinada cultura, dá origem a processos identitários "de fronteira" que se estendem numa longa duração.

A noção de identidade de fronteira torna mais complexa a ideia do antropólogo Fredrik Barth segundo a qual a continuidade das unidades étnicas "depende da manutenção de uma fronteira [boundary]" que diferencie o grupo interno do grupo externo (Barth, 1998: 14-15). De facto, se tomarmos a diferenciação entre "nós" e os "outros" como uma das estratégias identitárias mais básicas, com todos os seus critérios de inclusão e de exclusão, então dir-se-á que as identidades de fronteira são aquelas em que uma tal estratégia é sempre problemática, sempre em aberto e nunca resolvida. Nas identidades de fronteira, a hibridação significa que os "outros" estão intrinsecamente ligados a (e imersos em) "nós", por muito que "nós” tentemos excluí- "los", expeli-“los" ou simplesmente denegá- "los". ${ }^{1}$ Além disso, se quisermos basear a identidade nacional nalguma comunidade étnica, real ou imaginada (Smith, 1991: 19-41), teremos de reconhecer que as identidades nacionais construídas em processos "de fronteira" têm sempre dificuldade em localizar a linha de separação a partir da qual alguém é capaz de afirmar e de atribuir uma etnicidade. Em suma, e considerando ser a fronteira étnica aquilo que realmente define um grupo, e não "o conteúdo cultural que ela encerra" (Barth, 1998: 15), direi que, nas identidades de fronteira, a determinação das próprias "fronteiras", sempre instável e questionável, acaba por ser, em si mesma, o conteúdo maior da cultura.

Por fim, é toda a polaridade multidimensional dos processos de construção identitária que tem de ser reconsiderada à luz das identidades de fronteira. Com efeito, estas colocam em relevo a ambivalência estrutural que subjaz a esses processos. As identidades derivam do confronto e da síntese entre protótipos positivos e protótipos negativos (Erikson, 1994: 58, 299, $303,304)$, aos quais devemos acrescentar os protótipos idealizados e os denegados (Bastos, 1995: 932-937, 2000: 28). De acordo com José Pereira Bastos, a subjectividade é o espaço de articulação entre um "aquém identitário", definido por uma atitude ambivalente para com modelos negativos e modelos denegados, e um "além identitário", definido por uma atitude

\footnotetext{
${ }^{1}$ Utilizo por diversas vezes o conceito de denegação, baseando-me no seu sentido psicanalítico, para designar uma operação defensiva mediante a qual o sujeito se recusa a admitir um determinado conteúdo psíquico, um traço identitário ou uma experiência interior que, mau grado essa resistência, estão (ou continuam a estar) efectivamente inscritos nele (Laplanche e Pontalis, 1985: 373).
} 
ambivalente para com protótipos "meramente" positivos e para com protótipos mais do que positivos (isto é, idealizados). Ora, o que me parece típico das identidades de fronteira é, justamente, o facto de, devido à sua indecidibilidade, os referentes que representam, para o sujeito, o seu "aquém" e o seu "além" identitários não serem fixos nem estáveis, mas poderem substituir-se nessas respectivas posições.

Embora as identidades de fronteira não sejam exclusivas das estratégias que presidem à imaginação das identidades nacionais, são sobretudo estas que aqui me ocupam. Sugiro, pois, que muitos dos processos identitários que, na Rússia, foram construindo certas imagens de "comunidade cultural" diferenciada, ou de "nação", relevam daquilo que designo por "identidade de fronteira". Tal aplica-se não só aos momentos transicionais - os reinados de Ivan, o Terrível, e de Pedro, o Grande, os primórdios da industrialização na viragem do século XIX para o século XX, a Revolução Soviética e, possivelmente, as transformações a que assistimos desde os anos 80 e 90 -, mas também às constâncias ou às teimosias que atravessam a história dessa região como um magma profundo e estruturante. O posicionamento simbólico no espaço mundial, quer em termos geopolíticos, quer em termos culturais, foi a grande questão que muitos dos russos travaram (e continuam a travar) consigo mesmos. Foi também aí que a indecidibilidade e a ambivalência identitárias mais se manifestaram. Esse posicionamento deriva de um imaginário de "fronteira" mediante o qual os russos se viram (e se vêem) divididos entre a Europa e a Ásia (Figes, 2003: 66, 380). Uma divisão identitária que passa por ser matricial, pois parece remontar às raízes de um passado histórico. É no século XVI que Geoffrey Hosking (2003: 4-5, 21-22) situa os primórdios da oscilação bipolar entre o Oriente e o Ocidente, característica das construções políticas e culturais da Rússia. Boa parte das suas instituições, nomeadamente a comunidade aldeã (o famoso mir), teve origens asiáticas, mas, a partir do referido século, a Moscóvia começou a abrir-se, ainda que relutantemente, às influências do Ocidente europeu. Mesmo assim, até ao século XVII permaneceu uma economia-mundo autónoma, mais próxima do Leste que do Oeste (Wallerstein, s.d.: 293-314; Braudel, s.d.: 380-398). Com o reinado de Pedro, o Grande, iniciou-se a ocidentalização forçada, voluntarista e extensiva, uma dessas "revoluções a partir do topo" em que a Rússia tem sido versátil. O resultado não pôde deixar de ser contraditório, mais substancial na forma que no conteúdo, assente como foi num conhecimento superficial, e não raras vezes distorcido, da Europa. A partir daí, ao tornar-se parte integrante do sistema mundial capitalista, e como reacção a essa integração problemática, ambivalente e inacabada, a Rússia entrou também, pela mão daqueles que internamente 
a pensaram, na sua (in)definição identitária, dividida pela polaridade Oriente/Ocidente, pela hesitação entre a Ásia e a Europa.

Antes de prosseguir, impõem-se duas precisões. A primeira destina-se a situar a minha aplicação do conceito de identidade de fronteira face ao modelo analítico de que ela é subsidiária e que Boaventura de Sousa Santos tem vindo a desenvolver. Neste modelo, a metáfora da fronteira constitui uma estratégia para pensar a matriz semiperiférica da cultura portuguesa (1994: 133). Embora não haja aqui espaço para demonstrá-lo, existem bons motivos para pensar que a imaginação da Rússia também é indissociável de tal matriz. Por outro lado, aquele autor concebe a fronteira como a forma da cultura portuguesa, forma eminentemente móvel, "acêntrica", capaz de "canibalizar" todos os conteúdos porque vazia de conteúdo "próprio" (e só o "próprio" lhe é verdadeiramente estranho) (1994: 132-134). Esta concepção, se produtiva nos casos português e brasileiro, parece-me apenas parcialmente transponível para o contexto russo. ${ }^{2}$ Pegando na distinção elaborada por Santos, e na sequência do que sugeri atrás, eu diria que, na Rússia, a identidade de fronteira aparece como uma forma que já é, em si mesma, um conteúdo. Ou dois, consoante encaremos as construções identitárias na perspectiva da média ou da longa duração. Na primeira, a forma da identidade de fronteira, igualmente móvel e susceptível de se inscrever em diferentes cenários sociais, tem o conteúdo da própria realidade semiperiférica da Rússia, ${ }^{3}$ e as representações identitárias acusam uma espécie de inacabamento histórico, de suspensão entre o centro e a periferia, entre o arcaico e o moderno. Num certo sentido, as identidades semiperiféricas, enquanto identidades de fronteira, forneceram o ponto de vista mais constante pela qual um número significativo de russos experienciou (e concebeu) a modernidade. E seria talvez possível argumentar, mas tal não cabe neste

\footnotetext{
${ }^{2}$ Sublinho, porém, o "parcialmente", pois não podemos esquecer a abundância de discursos que, na Rússia, identificaram a experiência identitária com a vivência do vazio e, significativamente, com o recurso à mimese enquanto meio de compensar o que parecia ser ausência de conteúdo. Estes temas são particularmente notórios nas imagens da Rússia produzidas por alguns pensadores do século XIX, como Karamzine ou Tchaadaev, que tiveram imensa influência sobre os debates identitários desenvolvidos pela intelligentsia desse país.

3 A aplicação à Rússia - e mesmo ao "império" soviético - do conceito wallersteiniano de "semiperiferia" parece hoje relativamente pacífica. Com efeito, as opiniões dos investigadores convergem para uma mesma ideia: na transição do século XIX para o século XX, a Rússia era uma entidade ambígua, híbrida, numa posição intermédia ou mista entre o feudalismo e o capitalismo, entre o apelo modernizante da Europa e o apelo arcaizante da Ásia. "Formação social compósita", chamou Perry Anderson à autocracia russa de inícios do século XX, um "Estado feudal" paradoxalmente "dominado pelo modo de produção capitalista" (1979: 358). Quanto a Wallerstein, foi ele mesmo que aplicou a noção de semiperiferia para captar esta posição de intermediação da Rússia na economia mundial e no sistema inter-estatal (Wallerstein, 1979: 27, 31, 87). Já antes o economista Maurice Dobb antecipara essa classificação (1948: 34).
} 
texto, que é ainda o molde pelo qual boa parte deles experimenta, hoje, a sua inserção no mundo pós-comunista. Se, entretanto, passarmos à perspectiva da longa duração, a forma da identidade de fronteira reveste-se de outro conteúdo. Este é, como já foi referido, a inscrição da experiência identitária num espaço partilhado e indecidido entre a Europa e a Ásia, entre o Ocidente e o Oriente. Também aí a forma surge dotada de mobilidade e de uma quase ubiquidade, assumindo aspectos distintos ao longo das várias épocas da cultura russa.

Não obstante as diferenças que separam a aplicação do conceito de identidade de fronteira ao caso da Rússia e ao de Portugal, existem coincidências e pontos de contacto que abrem a possibilidade de uma sociologia e de uma antropologia comparativas dos processos identitários em diferentes sociedades semiperiféricas. Esse trabalho de comparação seria talvez a melhor maneira de começarmos a aferir constantes estruturais em sociedades que, separadas pela geografia e pelas trajectórias históricas, apresentam, contudo, afinidades de inserção no sistema mundial. ${ }^{4}$

A segunda precisão a fazer consiste em introduzir um princípio de prudência teórica. O tema da identidade de fronteira presta-se, com alguma facilidade, à essencialização, a essa retórica sobre a "alma russa", substantiva e perene, "alma" que apresentaria, justamente, o atributo de uma eterna indecidibilidade. Este deslize é perigoso, porque facilmente apropriável pelas ideologias que gostam de transformar o histórico em "essência". Para nos precavermos de semelhante risco, importa insistir na dimensão elaborativa das representações identitárias, isto é, no facto de estas serem construções através das quais os actores percepcionam o mundo envolvente, ao mesmo tempo que reagem a ele e o estruturam, tomando sempre como referência a sua própria inscrição enquanto sujeitos. Por conseguinte, quando aqui se falar de "a Rússia", convém lembrar que este é um artifício retórico (visto que "a Rússia" não faz, não pensa, não age). O conceito de identidade de fronteira deve, assim, ser perspectivado de três maneiras: (1) num sentido ontológico, enquanto forma efectiva de muitas das representações de identidade que os actores sociais, individuais ou colectivos, construíram em diferentes circunstâncias e em diversas épocas da cultura russa; (2) num sentido retórico, enquanto discurso (identitário) que as elites intelectuais e políticas da Rússia foram produzindo acerca da identidade russa: meditando essa identidade, tais elites elaboraram representações que podemos razoavelmente descrever como sendo "de fronteira"; (3) num sentido teórico, enquanto modelo explicativo que procura identificar e sintetizar a lógica

${ }^{4}$ Recentemente, ensaiei os primeiros passos para esse estudo comparativo em Machaqueiro, 2007. 
subjacente a certas tendências recorrentes nas construções identitárias russas. Embora estes três significados coexistam na análise que se segue, é conveniente não os confundir. Um enfoque especial será dado ao segundo sentido, não só por ser mais fácil o acesso às fontes onde podemos identificá-lo, mas sobretudo devido à influência social e política que as construções identitárias produzidas pela intelligentsia tiveram (e continuam a ter) sobre as trajectórias da sociedade russa.

Privilegiar o ponto de vista das elites introduz, contudo, problemas que importa não negligenciar. Sem ser propriamente um defensor dos méritos da história política - restringida às "personalidades históricas" - por oposição à história social, gostaria no entanto de sublinhar as dificuldades de empreender uma história social das representações identitárias de fronteira na Rússia. Estas resultam, desde logo, da escassez de fontes: só recentemente os investigadores começaram a desenterrar, nos arquivos, a documentação que registou o imaginário popular em época de revolução (von Geldern e Stites, 1995; Steinberg, 2001). Por outro lado, embora haja testemunhos que sugerem a presença de construções identitárias de fronteira entre as classes populares russas, a imaginação que lhes subjaz foi (e tem sido) particularmente visível entre as elites intelectuais e políticas, ao ponto de esse imaginário ter estruturado os principais debates da intelligentsia desde os anos 40 do século XIX até às primeiras décadas do século XX, debates que regressaram em força após o colapso da União Soviética.

As dificuldades não terminam, porém, aqui. Apesar de diversos autores salientarem o papel decisivo das elites culturais e políticas na elaboração das ideologias e dos mitos nacionalistas, sem os quais nenhuma identidade nacional seria concebível (Smith, 1991: 65-66, 93-97), o privilégio concedido à leitura dessa identidade na óptica das elites pode e deve ser questionado. Antes de mais, existe o problema intrincado de determinar a relação entre as percepções populares e a produção pela elite de modelos ou imagens do "nacional": será essa uma relação linear e mecânica, por meio da qual os discursos das elites se disseminam gradualmente no tecido social, evoluindo até se tornarem senso comum? Esta questão não pode obter uma resposta afirmativa quando pensamos nos muitos casos de incompreensão mútua entre as elites e o povo de cujas qualidades intrínsecas elas pretendem ser o único juiz, ou quando consideramos os vários exemplos de desmentidos dados às "intuições" das elites sobre a "sua" identidade nacional. Ao reduzirem esta última a uma visão essencialista da "alma do povo", os grupos culturalmente influentes dizem-nos mais sobre si mesmos do que sobre o objecto que supostamente deveriam explicar (Santos, 1994: 50, 57; Bastos, 1995: 545). É certo que, nas próximas páginas, a minha atenção foca sobre- 
tudo o discurso identitário dos líderes bolcheviques, inscrevendo-o na longa tradição de imaginário que a intelectualidade russa vinha produzindo desde o início do século XIX, e tendo em conta, aliás, que tais dirigentes pertenciam de pleno direito a essa "classe" tão complexa e problemática que foi a intelligentsia. ${ }^{5} \mathrm{O}$ referido discurso, porém, não será tomado como uma análise, intrinsecamente válida, de uma suposta identidade "russa", mas tão-só como sintoma de certas estratégias de construção identitária.

\section{Três estratégias identitárias para a Rússia}

A tese central deste artigo defende que a trajectória do bolchevismo reproduziu uma longa tendência de indecisão dos russos relativamente ao seu lugar geopolítico na Europa e no mundo. Essa tendência ocupou boa parte das preocupações intelectuais que antecederam a Revolução de 1917. Uma abordagem transversal das mesmas, impossível de fazer aqui, autoriza-nos a admitir que, em grande medida, as suas diferentes facetas procuraram responder ao sentimento depressivo com que Tchaadaev caracterizou o não-lugar da Rússia na sua famosa "Carta Filosófica" publicada em 1836, primeiro passo numa longa série de requisitórios sobre o atraso do país:

Uma das coisas mais deploráveis da nossa civilização singular é que ainda não descobrimos as verdades que, lá fora, são as mais triviais, mesmo em povos bem menos avançados do que nós sob certos aspectos. É que nós nunca caminhámos com os outros povos; não pertencemos a nenhuma das grandes famílias do género humano; não somos nem do Ocidente, nem do Oriente, e não temos as tradições nem de um, nem de outro. Situados como que fora do tempo, não fomos atingidos pela educação universal do género humano. ${ }^{6}$

Compreende-se que, na Rússia, as principais estratégias nas identidades de fronteira tenham visado, acima de tudo, superar o desconforto provocado por esta indefinição identitária. Consequentemente, esforçaram-se por reduzir a ambivalência e a indecidibilidade que a acompanhavam. Esse fim exigiu a rasura da dualidade identitária e a sua substituição por uma mono-

\footnotetext{
${ }^{5}$ Os estudos sobre a intelligentsia russa são legião. Alguns autores sustentam, a meu ver de forma discutível, que essa classe terá sido exclusiva da Rússia e originada por condições que só esse país pôde preencher. Entretanto, quase todos reconhecem o impacto considerável que ela teve na tradição revolucionária russa. A esse respeito, poderá consultar-se Berlin (1994), Figes (2003), Nahirny (1983), Pipes (1961) e Pomper (1970).

${ }^{6}$ O texto de Tchaadaev foi originalmente escrito e publicado em francês, a língua das elites estrangeiradas da Rússia no século XIX. O seguinte endereço da Internet contém a versão original: $<$ http://www2.unil.ch/slav/ling/textes/ChaadaevPremlettrephilo.html>. A citação foi traduzida a partir desta última fonte, ainda activa em finais de 2006.
} 
-identidade coesa. Ou, em alternativa, que a dualidade fosse convertida numa experiência feliz, puramente interna, sem um exterior que a ameaçasse ou a humilhasse. As estratégias que tentaram realizar estes objectivos podem, segundo creio, sintetizar-se em três categorias. A primeira assumiu a conotação negativa atribuída à identidade etnonacional, mas não subscreveu a sua essencialização. Reconhecendo-lhe um estatuto inferior frente a identidades mais "elevadas" ou "avançadas", não o viu, porém, como uma fatalidade incontornável, mas como o ponto de partida para um projecto de revalorização identitária e de reinvestimento narcísico. Com ele, as "insuficiências" de origem seriam ultrapassadas mediante a absorção das qualidades atribuídas às identidades "de topo". A segunda estratégia desenvolveu um duplo esforço de diferenciação ou desidentificação identitária, recusando simultaneamente quer os referentes negativos, quer os modelos positivos que os discursos estrangeiros dominantes pretendiam impor à identidade etnonacional. Aquilo que aí costumava ser apresentado como modelo positivo via-se agora criticado e rejeitado, ao passo que a identificação negativa era pura e simplesmente evacuada. O sujeito afirmava então uma "terceira via", na qual a identidade nacional não relevava nem do referente anteriormente negativo, nem do positivo. A terceira estratégia foi diametralmente oposta à primeira. Inverteu a hierarquia das boas e das más pontuações atribuídas aos modelos identitários, convertendo o negativo em positivo e vice-versa. Tal estratégia visava desafiar as identidades dominantes no sistema mundial de relações de poder, devolvendo-lhes os mesmos qualificadores pejorativos que elas usavam para justificar a existência de identidades subalternas.

Todas estas estratégias possuíam, elas próprias, uma indecidibilidade intrínseca, pelo que nenhuma operou de forma "pura". Elas constituem tipos-ideais, nada impedindo um mesmo sujeito de transitar ambivalentemente entre elas. É possível relacioná-las com as três principais correntes intelectuais que, na Rússia do século XIX, disputaram as interpretações sobre a identidade russa e cujo vocabulário transparece ainda no discurso que os bolcheviques vieram a produzir sobre esse território imaginário. Assim, a primeira das estratégias que acabámos de mencionar correspondeu à corrente oitocentista conhecida por "ocidentalismo", especialmente activa durante as décadas de 1840 e 1850 . As suas figuras mais proeminentes, Aleksandre Herzen, Turgueniev e Bielinski, começaram por apostar tudo num suposto universalismo de raiz europeia, graças ao qual o localismo russo deveria ser superado e redimido do seu atraso. A segunda estratégia identitária teve o seu suporte principal no eslavofilismo, corrente que se desenvolveu em paralelo com a sua rival, o ocidentalismo, e cuja influência transcendeu largamente o século que a viu nascer (Walicki, 1989). 
Sendo uma reacção contra o culto da Europa Ocidental, a tendência eslavófila reformulou a diferença russa como algo que deveria ser acarinhado em vez de subestimado. Finalmente, a terceira estratégia foi encarnada, sobretudo, por uma corrente do século XX, o eurasismo, que surgiu entre os intelectuais exilados na sequência da Revolução de Outubro, tendo sido talvez a que levou mais longe a recusa da via ocidental para a construção da identidade russa. Trubetskoi, um dos criadores da linguística estrutural, foi também o principal fundador desse movimento, ligando-o à percepção do "esmagamento identitário" alegadamente produzido pela aculturação das populações não-europeias, forçadas a assimilar a cultura da Europa Ocidental. ${ }^{7}$

Como referi atrás, as construções identitárias desenham mapas complexos, cujo centro é ocupado pela oposição entre dois pólos, um negativo e outro positivo. Sendo o segundo pólo objecto de exaltação, o primeiro é o alvo de todas as repressões e exclusões. Por sua vez, essa oposição reporta-se a outros referentes, em função dos quais é organizada: um referente denegado (inconsciente, oculto, vergonhoso, não-assumido) e um referente idealizado, sobre o qual uma parte do sujeito investe o seu projecto de autotranscendência. A identidade ideal é uma derivação da identidade positiva, mas integra uma dimensão futurante ou utópica que esta última não comporta, limitada que está ao possível e ao actual. Em cada uma das correntes que acabei de mencionar, as estratégias citadas definiram relações próprias entre todos estes pólos de referência. Assim, o espaço imaginário do ocidentalismo opôs uma identidade negativa (onde se misturavam o "asiático", o "tártaro" e o "atrasado") a uma identidade positiva (coincidente com o "europeu”). Nesse espaço, a identidade negativa repercutia-se sobre a denegada (constituída pelo "russo-bárbaro" ou "russo-selvagem") e a identidade positiva transcendia-se numa identidade ideal (representada pelo "russo europeizado" ou pelo "russo cosmopolita"). Já o mapa eslavófilo apresentava maior complexidade: nele, a identidade positiva (o "russo-eslavo" ou o "russo-ortodoxo") vinha compensar a identidade denegada (de novo, o russo "bárbaro" ou "selvagem"), enquanto a identidade ideal constituía a universalização do referente tido como positivo: o fim último seria, pois, o triunfo de um "russo universal" cujo exemplo seria seguido por todos os povos. Finalmente, o mapa eurasista exibia uma dinâmica de funcionamento similar ao eslavófilo, com a diferença de que, nele, a imaginação universalista

\footnotetext{
7 Sobre o eurasismo e outras correntes que lhe foram afins, como o "nacional-bolchevismo", ver Halperin (1982), Burbank (1986), Hardeman (1994) e Shlapentokh (1997). Os principais ensaios eurasistas de Trubetskoi encontram-se reunidos em Trubetskoi, 1991.
} 

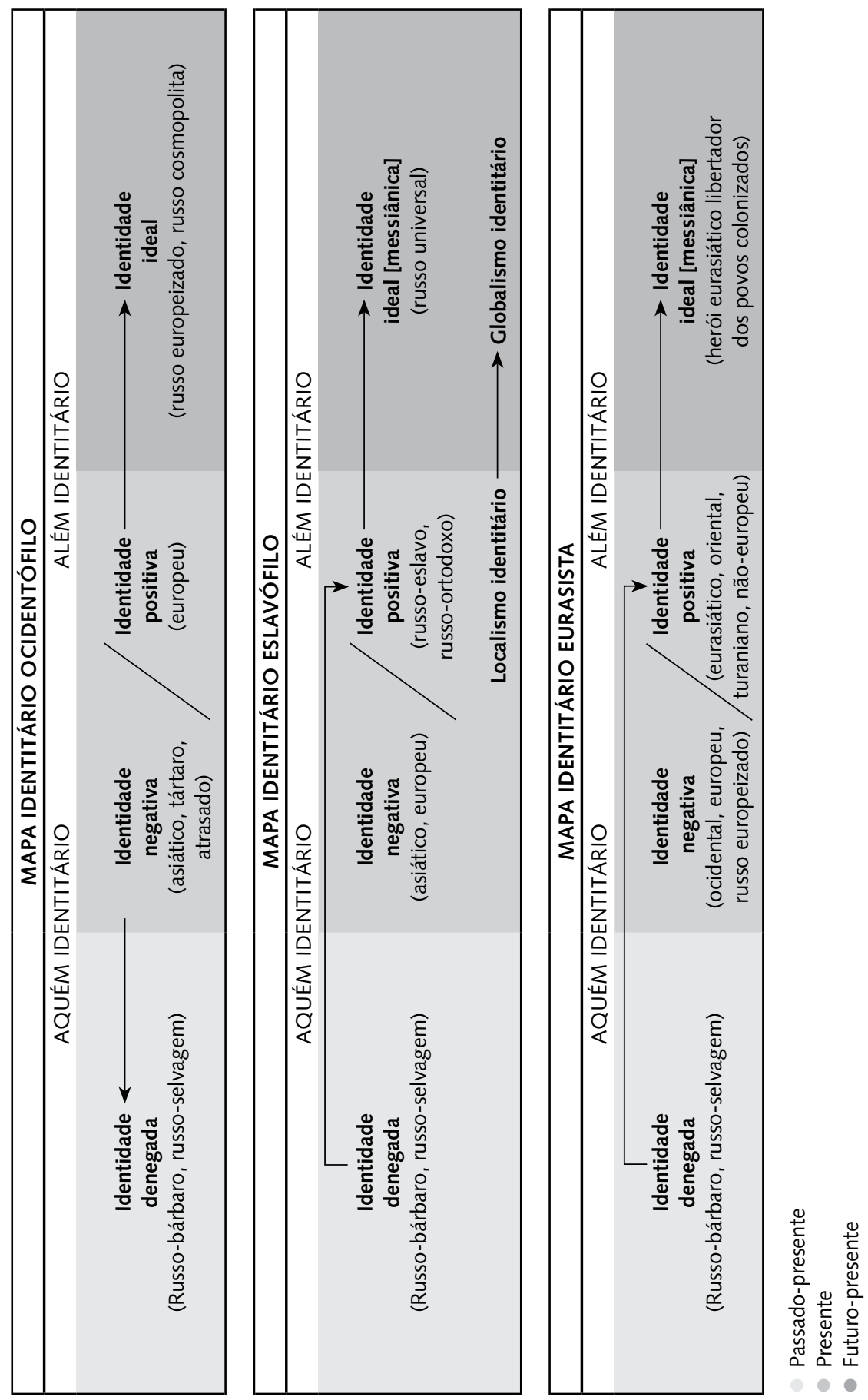
era menos óbvia ou mais ambivalente: o "russo-eurasiático" (a identidade positiva) permanecia cioso da sua diferença em relação ao pólo negativo, preenchido pelo "ocidental" imperialista, pelo "europeu" arrogante e, claro, pelo "russo europeizado". No eurasismo, o referente denegado continuou a ser o "russo bárbaro", sempre embaraçoso, mas essa corrente foi também percorrida por uma tensão entre o universalismo e a tentação de fechamento autárquico dentro das fronteiras da Rússia-Eurásia. Semelhante tensão projectou-se sobre a identidade ideal, o "herói eurasiático libertador dos povos colonizados [pelos ocidentais]", tornando-a fortemente ambígua.

Se o ocidentalismo permaneceu sóbrio nas suas pretensões - foi aí, afinal, que o liberalismo russo bebeu a sua inspiração -, já o eslavofilismo e o eurasismo condensaram alguns dos aspectos mais marcantes daquilo que muitos definiram como o messianismo russo: a ideia, compensadora em vista de sucessivas humilhações identitárias, de que caberia aos Russos desempenhar uma missão redentora e salvífica para toda a humanidade. Sobre esse messianismo muitos rios de tinta correram, como também correram a respeito da influência que ele exerceu na tradição revolucionária russa, e no bolchevismo em particular. ${ }^{8}$

Não é fácil encontrar ecos explícitos destas correntes nos textos redigidos pelos principais teóricos e líderes do bolchevismo - Lénine, Trotski e Bukhárine. Só Plekhánov, o fundador do marxismo russo, dedicou às duas primeiras alguns estudos importantes, chegando mesmo a interpretar a história da Rússia como uma luta entre o elemento asiático e o elemento ocidental, na qual os marxistas militavam a favor do segundo (Walicki, 1989: 12, 49-51). Em boa verdade, o objecto identitário propriamente dito não foi tematizado nas reflexões dos marxistas russos. Os seus modelos cognitivos, de cariz acentuadamente determinista, não se mostravam sensíveis a uma tal problemática. Daí que o economismo os tenha levado a afunilar as questões de cultura e de identidade na mera perspectiva "de classe". Contrariamente aos austromarxistas Otto Bauer e Karl Renner, Lénine não admitia a existência de "culturas nacionais", visto que, segundo ele, apenas havia culturas socioeconomicamente determinadas, isto é, inerentes a classes sociais. A "cultura nacional” não era senão a da burguesia enquanto classe dominante (Pipes, 1957: 43; Carrère d'Encausse, 1987: 56-57). Depreende-se, pois, que só existiriam identidades de classe - tal como toda a consciência é, verdadeiramente, uma "consciência de classe". Mesmo assim, como tentarei mostrar neste artigo, julgo ser possível assinalar, em diferen-

${ }_{8}$ Acerca do messianismo e do escatologismo russos, ver Lotman e Uspenskij (1984: 54-56) e Averintsev (1991: 18-20). 
tes momentos da estratégia política do bolchevismo, a emergência de temas identitários que prolongam os debates do século XIX. Mais ainda: ao longo dos primeiros anos de consolidação do poder bolchevique, podemos observar os seus líderes a inscreverem, alternadamente, os processos de construção de uma "identidade russa" dentro de cada uma das três estratégias referidas atrás.

\section{A Revolução Soviética entre o Ocidente e o Oriente: um percurso iden- titário}

O ponto nodal onde a indecidibilidade "originária" da cultura russa afectou o pensamento marxista foi, desde logo, a natureza e a oportunidade de uma revolução na Rússia. Todas as facções da social-democracia começaram por ser, a este respeito, inequivocamente ocidentalistas. A eventualidade de uma revolução russa gravitava na órbita da revolução ocidental, isto é, de uma revolução socialista destinada a emergir, em primeiro lugar, nos países de capitalismo avançado, os únicos capazes de reunir as condições estipuladas pelos clássicos do materialismo histórico. Sem o eclodir de tal revolução nos países europeus mais desenvolvidos, nunca uma revolução socialista poderia singrar na Rússia, a qual teria de se contentar com uma revolução burguesa. A história não dá saltos: era esse o dogma, que servia aliás para distinguir os marxistas dos populistas, estes últimos crentes na transição directa do feudalismo para o socialismo.

Como é sabido, a outra facção da social-democracia russa, a dos mencheviques, manteve-se até ao fim fiel à concepção ortodoxa. Não é este o lugar para analisar em pormenor o conflito que veio a dividir mencheviques e bolcheviques a respeito da natureza da revolução. ${ }^{9}$ Também não pretendo afirmar que este e outros conflitos do mesmo género se limitaram a traduzir, consciente e linearmente, as dualidades e as ambivalências da identidade de fronteira, das auto-imagens (pessoais, culturais, nacionais e étnicas) que ela sugeria. Mas acho sustentável, como hipótese a explorar, que essa problemática identitária atravessou, ainda que de forma oblíqua, tais divergências sobre a definição e a estratégia da revolução. Pois todas se debatiam com um problema claramente herdado daquela construção identitária: a diferença da Rússia no espaço europeu.

\footnotetext{
${ }_{9}$ O livro de Haimson (1966) constitui o estudo clássico das origens da cisão entre bolcheviques e mencheviques, a qual, recordemo-lo, ocorreu em 1903, no Segundo Congresso do Partido Operário Social-Democrático Russo. Para a história específica do menchevismo através de um enfoque nas suas principais figuras, Axelrod e Martov, ver Getzler (1967) e Ascher (1972); no que respeita à evolução das diferentes tendências mencheviques durante a Revolução de 1917 e após a tomada do poder pelos bolcheviques, cf. Galili (1989), Haimson (1974) e Brovkin (1987).
} 
Foi talvez em Lénine que esta discussão sobre a natureza da revolução russa manifestou, com maior acuidade e consequências de vulto, a tensão identitária entre o "russo" e o "europeu". A este respeito, dir-se-ia mesmo que o líder bolchevique perfilhou, em diferentes pontos da sua trajectória, uma ou outra das três estratégias atrás referidas e das correntes intelectuais que lhes deram expressão. O confronto entre as imagens do "russo" e do "europeu" deu-se, pois, num quadro variável que distinguia uma identidade potencialmente denegada (a "russa") de duas outras (a "asiática" e a "europeia") com as quais Lénine se relacionou de modo ambivalente, classificando-as alternadamente ora como positiva, ora como negativa (Lewin, 1969: 106-108; Harding, 1981: 253-254).

A identidade de fronteira da Rússia era algo de que Lénine estava bem ciente. Criticando a visão dos mencheviques sobre a Revolução de Outubro, afirmou

[...] que a Rússia, situada na fronteira entre os países civilizados e os países que pela primeira vez são arrastados definitivamente por esta guerra para o caminho da civilização, os países de todo o Oriente, os países não europeus, que a Rússia podia e devia, por isso, revelar certas peculiaridades, que naturalmente estão na linha geral do desenvolvimento mundial, mas que distinguem a sua revolução de todas as revoluções anteriores dos países da Europa Ocidental e que introduzem algumas inovações parciais ao deslocar-se para os países orientais. (1979: 664)

Tão consciente era dessa condição de fronteira que chegou a ver nela um dos factores para o próprio pioneirismo revolucionário da Rússia:

Devido a uma série de circunstâncias - entre outras o atraso da Rússia, a sua enorme extensão e o facto de servir de fronteira entre a Europa e a Ásia, entre o Ocidente e o Oriente - tivemos de suportar todo o peso - que consideramos uma grande honra de sermos os pioneiros da luta mundial contra o imperialismo. (Lénine, 1979: 210)

Posto isto, urgia saber para qual dos pólos dessa hibridação identitária a Rússia se devia inclinar mais: para o ocidental-europeu ou para o asiático. Responder a esta questão equivalia a delinear toda uma estratégia de transição histórica para esse país. Confrontado com o dilema, Lénine revelou-se tão flutuante como a própria realidade social que o rodeava. Durante muito tempo, foi o pólo ocidental que ele claramente privilegiou, em consonância com uma longa tradição do marxismo. Nessa linha, os bolcheviques exibiam a convicção de que a "guerra imperialista" (de 1914-18) iria tornar-se "guerra civil", enquanto "guerra de classes" "travada pelos oprimidos contra os seus 
opressores", de onde nasceria a tão almejada revolução mundial. Todavia, consumada a conquista do aparelho de Estado pelos bolcheviques, Lénine, que sempre se mostrara céptico em relação a esses movimentos "irresistíveis" da história, começou a preparar os seus correligionários para o arrefecimento da revolução socialista na Europa e a multiplicar os sinais de prudência - ele que tinha sido tão imperativamente ousado em Outubro de 1917. Estas suas cautelas remontavam às negociações de paz com a Alemanha em Brest-Litovsk, um momento por certos autores considerado como de ruptura na história da Revolução Bolchevique (Liebman, 1973: 28-30, 229). Nessa altura, opondo-se aos "comunistas de esquerda" liderados por Bukhárine, que pretendiam a todo o custo prolongar a guerra, desta feita revolucionária, contra a Alemanha, convictos de que o proletariado alemão os apoiaria na retaguarda, Lénine esforçou-se por contrariar esse fervor (Daniels, 1960: 71-80; Kowalski, 1991: 60-79). Daí em diante, todo o percurso da sua reflexão e prática política será orientado para a reconciliação com a ideia de que “a revolução não chegará tão depressa como esperávamos" (1978: 505), ideia tão distante das premissas que tinham inspirado a tomada do poder em Outubro (embora Lénine, sempre ambivalente nas suas posições, nunca tenha renunciado inteiramente à perspectiva da revolução europeia-ocidental). É escusado frisar como as flutuações de tal percurso tornam difícil identificar paradigmas políticos na acção de Lénine e dos seus camaradas bolcheviques. A navegação misturava a aventura no mar alto com a arte da cabotagem, a aprendizagem por insight com a aprendizagem por ensaio e erro. Tudo muito ideológico, sem dúvida, mas pouco paradigmático.

Lénine vivia na fronteira. E sabia-o. A sua postura não foi, por isso, simplesmente eurocêntrica. Em meados dos anos 20, a frustração com o "atraso" (ou com a pura ausência) da revolução socialista na Europa "avançada" talvez tenha sido simétrica da desilusão experimentada frente à atitude belicista dos socialistas europeus na explosão da Primeira Guerra Mundial (Harding, 1981: 6-9, 12-19; Service, 1991: 71-72). Quando o pressuposto dessa revolução começou a revelar-se cada vez mais infundado, o líder dos bolcheviques voltou as suas atenções para o outro pólo da identidade russa: o Oriente.

Nisso não estava sozinho. Já em 16 de Maio de 1918, quando se pensou em instituir a República Soviética Autónoma Tátara-Bachkir, ${ }^{10}$ Stáline relacionara o apoio soviético aos povos do Oriente com a posição "de fronteira"

${ }^{10}$ Esta república acabou por não ver a luz do dia. Em seu lugar, foram criadas duas "repúblicas autónomas", a de Tatarstan e a de Bachkiria, com dimensão e estatuto inferiores aos das "repúblicas federadas" (Taibo, 1999: 65). 
da Rússia. Posição que não era apenas "objectivamente" geo-gráfica, mas também geo-política (e, portanto, simbólica e imaginária), se tivermos em conta os adjectivos com que Stáline classificava as duas áreas do mundo entre as quais a Rússia definia a sua identidade:

Todo o carácter da nossa revolução, a própria natureza do governo soviético, a situação internacional geral, e, por fim, até a posição geográfica da Rússia, situada entre a Europa imperialista e a Ásia oprimida - tudo isto impele necessariamente o governo soviético a adoptar a política de apoio fraternal aos povos oprimidos do Oriente na sua luta pela sua própria libertação. (Eudin e North, 1957: 46-47)

Trotski, por seu turno, embora inclinado a conceder a primazia à Europa, veio, mesmo assim, pugnar pela necessidade de reorientar para Oriente o investimento estratégico na revolução. Numa carta secreta de 5 de Agosto de 1919, endereçada ao Comité Central do Partido Comunista, ele inferiu a conclusão possível dos actos falhados desse longo ano - o fim da República Húngara de Béla Kun e o colapso da breve experiência "soviética" na Baviera. Sem deixar de dizer que "o tempo presente é tal que grandes acontecimentos no Ocidente podem materializar-se subitamente, mesmo num curto período", Trotski tinha de reconhecer que "o estrangulamento da República Húngara e a continuação do apoio aberto à campanha contra a Rússia são sintomas que indicam que o período preparatório, de incubação, da revolução no Ocidente pode demorar ainda, de facto, um tempo considerável" (Meijer, 1964: 621). Daqui Trotski infere que "a Ásia pode tornar-se a arena dos próximos levantamentos" e que a tarefa requerida aos comunistas é "efectuar, no momento oportuno, o necessário desvio do centro de gravidade da nossa orientação internacional” (ibid.: 627). Este desvio estratégico é imposto pelo próprio rumo dos acontecimentos (pela "vida", como diria Lénine): as cidades perdidas e as recuperadas na Guerra Civil mostram, "sem sombra de dúvida", "que retirámos do Ocidente para o Oriente” (ibid.). A lição maior que Trotski pretende extrair é a utopia de uma revolução mundial cavalgando o expansionismo soviético (ou vice-versa). Pois o então Comissário de Guerra giza todo um cenário de acções bélicas que a reorientação para o Oriente podia proporcionar:

Não há qualquer dúvida de que o nosso Exército Vermelho constitui uma força incomparavelmente mais poderosa no terreno asiático da política mundial do que no terreno europeu. Aqui abre-se diante de nós uma possibilidade incontestável, não apenas de uma espera prolongada, para ver como os acontecimentos se desenvolvem na Europa, mas de conduzirmos a actividade no campo asiático. O caminho para a 
Índia pode revelar-se, num dado momento, mais facilmente transitável e curto, para nós, do que o caminho para a Hungria soviética. O tipo de exército que, actualmente, pode não ter grande significado nos pratos da balança europeia é capaz de perturbar o equilíbrio instável dos relacionamentos asiáticos de dependência colonial, dar um impulso directo a uma insurreição por parte das massas oprimidas e garantir o triunfo de um tal levantamento na Ásia. (Meijer, 1964: 623)

Sem sair da metáfora das vias de circulação, Trotski torna-se ainda mais transparente, ao afirmar que "a situação internacional está, evidentemente, a tomar forma num sentido tal que a estrada para Paris e Londres reside nas cidades do Afeganistão, do Punjab e de Bengala" (ibid:: 625). Seja como for, e apesar de Trotski, noutros textos, se mostrar sensível à condição semiperiférica e híbrida da Rússia, nesta carta, assaz significativa, o Oriente aparece como algo essencialmente estranho ou exterior ao seu país, um meio de subverter a Europa, mas não uma componente intrínseca da identidade russa.

Com Lénine, em contrapartida, tudo se complica. E tudo se joga nas flutuações com que são identificados os lugares, a um tempo políticos e identitários, do "avanço" e do "atraso" em matéria revolucionária. Desde logo verificamos que a reorientação proposta por Trotski tinha raízes antigas no pensamento leniniano. Já em Janeiro de 1905 o futuro dirigente do Estado soviético se regozijara com a queda de Port Arthur às mãos dos Japoneses, dizendo que "a Ásia avançada e progressista tinha desferido um golpe irreparável na Europa atrasada e reaccionária" (Lénine, 1965: 48). ${ }^{11}$ Esta redistribuição das posições "progressista" e "atrasada", baralhando os hábitos de atribuição identitária, é típica de Lénine: reencontramo-la nos escritos finais da sua vida. Em 1908, ele pensara o lugar da revolução russa numa geopolítica da insurreição mundial onde a Ásia assumia um significado considerável (Lénine, 1963: 182-188). Com o desenvolvimento da teoria do imperialismo, em 1916, Lénine acentuou ainda mais a articulação entre as lutas nos "países avançados" e as lutas das "nações subdesenvolvidas e oprimidas". As duas categorias de regiões do mundo podiam ser assimétricas quanto ao desenvolvimento económico e cultural, mas estavam em pé de igualdade quanto à capacidade insurreccional (Carr, 1966: 434).

\footnotetext{
${ }^{11}$ O episódio da queda de Port Arthur ocorreu durante a Guerra Russo-Japonesa de 1904-1905, em torno do controlo da Manchúria e da Coreia, guerra marcada por uma sucessão de desaires humilhantes para a Rússia e pela destruição quase completa da sua armada. Na verdade, desse conflito emergiu um peculiar trauma identitário provocado pela primeira grande derrota de uma nação (que se queria ver como) "ocidental" às mãos de um país "oriental". O desfecho da guerra esteve também na origem da primeira revolução russa do século XX, a de 1905.
} 
Todavia, o primado do movimento emancipatório continuou, por muito tempo, a ser atribuído ao Ocidente sobre o Oriente, à iniciativa do proletariado das metrópoles exploradoras sobre as lutas de libertação nas colónias. Em 1919, o Manifesto da Internacional Comunista, redigido por Trotski, era muito claro quanto a estas hierarquias:

Nenhuma emancipação das colónias é possível a menos que as classes trabalhadoras da metrópole se emancipem. Os operários e camponeses, não só em Anam, Argélia, Bengala, mas também na Pérsia e na Arménia, atingirão a sua independência apenas na hora em que os trabalhadores de Inglaterra e da França derrubarem Lloyd-George e Clemenceau e tomarem o poder nas suas próprias mãos. [...] Se a Europa capitalista envolveu à força as partes mais atrasadas do mundo no remoinho das inter-relações capitalistas, a Europa socialista está preparada para auxiliar as colónias emancipadas através da sua técnica, da sua organização, da sua moral e influência intelectual, de modo a facilitar a transição daquelas para uma economia socialista devidamente organizada. Escravos coloniais da África e da Ásia! Quando soar a hora da ditadura do proletariado na Europa, terá chegado a hora da vossa libertação. ${ }^{12}$

Quando Lénine, em Novembro do mesmo ano, se dirigiu aos comunistas representantes das organizações muçulmanas do Oriente, mostrou-se muito mais matizado. $\mathrm{O}$ argumento avançado invertia, de novo, a relação de dependência. É verdade que, nele, a revolução russa e a revolução asiática eram condição necessária, mas nunca suficiente, para o triunfo efectivo do socialismo, visto que "só o proletariado de todos os países avançados do mundo pode alcançar a vitória definitiva” (Lénine, 1979: 217). Contudo, Lénine vincava bem que esse proletariado mais "desenvolvido" não conseguiria vencer "sem a ajuda das massas trabalhadoras de todos os povos coloniais oprimidos, e em primeiro lugar dos povos do Oriente". Tratava-se de fazer oscilar o pêndulo numa direcção que, afinal, o líder bolchevique já tinha aberto em 1916: "Iremos exercer todos os esforços para fomentar a associação e a fusão com os Mongóis, os Persas, os Indianos, os Egípcios. Acreditamos que fazer isto é o nosso dever e é no nosso interesse, pois de outro modo o socialismo na Europa não estará seguro" (1964: 67).

Estrategicamente inovadora, esta noção não podia, no entanto, gerar ainda todo o seu potencial. O que a impedia de florescer era a imagem identitária depressiva do Oriente, uma imagem que, de resto, explicava o vínculo especial estabelecido por Lénine entre a Rússia e o espaço oriental.

12 "Manifesto of the Communist International - To the Proletarians of the World", The Communist International, 1, Maio de 1919, 12-13. Sobre a autoria deste texto, ver Daniels, 1987: 34. 
Segundo ele, o país dos sovietes, o "mais atrasado da Europa”, tinha uma afinidade com o Oriente: "Nós realizámos no nosso país, em pequena escala, aquilo que vós realizareis em grande escala, em grandes países”. E a missão dos russos e dos povos orientais derivava da sua inserção, periférica e semiperiférica, na economia mundial: enquanto populações "atrasadas", deveriam prestar assistência à revolução proletária na Europa mediante o derrube dos seus sistemas ainda feudais.

Portanto, nesta fase do seu pensamento, Lénine não lograva imaginar, para o Oriente e para a própria Rússia, mais do que uma tarefa "assistencialista" relativamente à revolução proletária na Europa. Este lugar modesto reservado para a Rússia (Liebman, 1973: 298-300), e as afinidades que a aproximavam de um Oriente colonizado, replicavam a representação ocidentalista dos atributos "asiáticos" desse país. Há textos de Lénine que reproduzem toda uma tradição de construções identitárias, identificando a "Ásia” com a "barbárie", e onde o autor fala de uma "incultura semi-asiática, da qual não conseguimos sair até agora e da qual não conseguiremos sair sem sérios esforços" (Lénine, 1979: 654). A "Ásia" fornecia aqui a sinédoque para o famoso "atraso russo", em desvantagem comparativa face à "Europa". A isto somava-se o peso da tradição: a imagem desvalorizante da Rússia deixara um longo rasto no marxismo ocidental, começando pelo próprio Marx, cujo desprezo por esse país foi vertido com todos os estereótipos da sua imagem orientalizante:

[...] É na escola terrível e abjecta da escravatura mongol que a Moscóvia se formou e cresceu. Ela só ganhou a sua força por se tornar virtuosa na arte da servidão. Mesmo após a sua emancipação, a Moscóvia continuou a desempenhar o seu papel tradicional de escravo disfarçado de senhor. Foi, enfim, Pedro, o Grande, que combinou a arte política do escravo mongol com a aspiração orgulhosa do senhor mongol a quem Gengis Khan legou, por testamento, a conquista do mundo. ${ }^{13}$

Mesmo alguns simpatizantes asiáticos da causa bolchevique tinham interiorizado, eles próprios, esta sua imagem inferiorizada, e aceitavam o patrocínio paternalista dos seus camaradas ocidentais ou ocidentalizados. Essa postura vinha, pois, reproduzir/confirmar as hierarquias identitárias que punham o Oriente numa relação de desvantagem perante o Ocidente. O discurso dos membros muçulmanos do Partido Comunista Russo, que,

\footnotetext{
${ }_{13}$ Revelations of the Diplomatic History of the Eighteenth Century, em <http://www.marxists.org/ archive/marx/works/1857/russia/ch04.htm>. É curioso verificar como, neste trecho, Marx atribui a Pedro, o Grande, traços (inferiorizantes) "asiáticos" e "mongóis", a contrapelo de toda uma tradição interpretativa que vê nesse czar a primeira grande encarnação de um projecto ocidentalista para a Rússia.
} 
em Dezembro de 1918, se dirigiram ao seu próprio grupo étnico, é uma ilustração cabal do que acabei de referir. Nele, a assimetria identitária entre Ocidente e Oriente era veiculada por outra assimetria fantasmática, de tipo familialista, sempre à mão quando se trata de simbolizar uma relação de desigualdade: a diferença hierárquica entre o "adulto" e a "criança", esta última representada pela figura dos "irmãos mais novos":

Camaradas muçulmanos! Os acontecimentos que estão a ter lugar no mundo, a vitória, cada vez mais próxima, da revolução socialista mundial, induzem-nos a prestar uma atenção particular aos povos mais atrasados do Oriente.

As ideias que foram quase plenamente assimiladas pelos camaradas mais cultivados do Ocidente são pouco conhecidas pelos camaradas no Oriente. Todos os comunistas têm o dever de vir em auxílio dos seus irmãos mais novos. (Eudin e North, 1957: 162)

Contudo, nos primeiros anos do Comintern, alguns revolucionários provenientes desse Oriente colonizado começaram a romper com o eurocentrismo destas representações negativas do "asiático". Em 1919, o tártaro Sultan Galiev escreve uma série de artigos onde considera que os líderes comunistas cometeram um erro estratégico ao concentrarem todos os seus esforços na Europa Ocidental, visto que o elo mais fraco do sistema capitalista reside no Oriente e não no Ocidente. Homens como Galiev defendem então uma mudança de rumo, uma alteração de Gestalt, capaz de inserir o ponto de vista oriental num esquema teórico que, até então, se mantivera essencialmente eurocêntrico: a acção revolucionária futura deverá focalizar-se nos povos do Oriente, com o cuidado de atender às suas particularidades culturais (Pipes, 1957: 169-170). Em 1920, durante o Segundo Congresso da Internacional Comunista, também Manabendra Nath Roy, representante das Índias britânicas, vem sustentar que o triunfo do socialismo na Europa exige, em absoluto, uma revolução no Oriente (Suny, 1993: 92). Ora, o argumento de Roy estava a procurar extrair todas as potencialidades da dependência em que a revolução europeia se achava face ao Oriente, conforme Lénine já havia insinuado no Relatório de 1919 às Organizações Comunistas dos Povos do Oriente. Esse argumento anunciava o "terceiro-mundismo" da década de 60, quando o "aburguesado" proletariado europeu foi substituído pelos povos dos países "subdesenvolvidos" no lugar de agente histórico da emancipação:

A mais-valia obtida pela exploração das colónias é o sustentáculo principal do capitalismo contemporâneo, e a classe operária só conseguirá derrubar a ordem capitalista quando esta fonte tiver sido definitivamente bloqueada. [...] Graças à exploração das massas nas colónias, o imperialismo europeu estará em condições de oferecer à 
aristocracia operária uma concessão atrás da outra. [...] Esse mesmo imperialismo europeu não hesitará em ir ao ponto de sacrificar a totalidade da mais-valia ganha nos seus próprios países, desde que possa continuar a extrair uma enorme mais-valia da exploração das colónias.

A destruição dos impérios coloniais, em conjunto com a revolução proletária nas metrópoles, derrubará o sistema capitalista na Europa. ${ }^{14}$

Isto implicava pôr a revolução socialista europeia a reboque de movimentos nacionalistas, burgueses e não-proletários, emergentes nas colónias. O debate agitado que esta concepção desencadeou alimentou-se da velha polaridade identitária entre o Ocidente (desenvolvido) e o Oriente (atrasado). Na altura, Lénine recusou o orientalismo de Roy, considerando que ele tinha levado demasiado longe a tese da dependência da revolução ocidental relativamente aos povos asiáticos, e procurou o meio-termo entre essa posição e o ocidentalismo intransigente sustentado por outro membro proeminente do Comintern, o italiano Serrati, que continuava a localizar na Europa o centro da revolução mundial (Eudin e North, 1957: 40).

De 1920 a 1923, o próprio Lénine foi multiplicando os apelos de confiança no movimento revolucionário dos países orientais, ao invés de outros social-democratas cujo eurocentrismo os impedia de reconhecer aí o fermento da revolução socialista mundial (Lénine, 1979: 526, 607, 652). Para a posição do líder comunista, também devem ter contribuído as desilusões desse ano de 1920 em que apostara tudo numa via revolucionária europeia, estratégia da qual resultara um desastre rotundo e comprometedor. ${ }^{15}$ Agora,

\footnotetext{
${ }^{14}$ Roy, "Discours au 2. ${ }^{\circ}$ Congrès de l'I.C." [Julho de 1920] (http://www.marxists.org/francais/roy/ works/1920/07/mnroy_19200700.htm). Transcrevi a primeira frase deste trecho de acordo com a versão original de Roy. O seu discurso era um conjunto de teses complementares das que Lénine apresentara sobre o mesmo assunto, e destinava-se, portanto, a ser discutido e modificado. A comissão encarregada da questão colonial no Segundo Congresso da Internacional Comunista alterou a segunda oração da frase acima referida, alteração que visava não colocar a revolução europeia sob a dependência absoluta de uma revolução nas colónias: "[...] enquanto [o capitalismo] não tiver sido privado desta fonte [a exploração das colónias] de mais-valia, não será fácil para a classe operária europeia derrubar a ordem capitalista". A tradução das teses de Roy em Eudin e North (1957: 66) só dá conta desta versão modificada.

${ }^{15}$ Lembremos que Lénine se tinha então empenhado pessoalmente em transformar a ofensiva do exército russo contra a incursão dos Polacos na Ucrânia, reorientando-a para uma invasão da Polónia no intuito de tomar a "sovietização" desse país como ponto de partida para uma subversão revolucionária no centro do sistema imperialista mundial. Em Agosto de 1920, porém, o Exército Vermelho saiu completamente derrotado e a inversão das forças foi de tal ordem que os Polacos chegaram a acalentar a ideia de serem eles, por sua vez, a avançar sobre Moscovo. O sonho de transformar a guerra civil russa em guerra revolucionária mundial, o sonho de despertar a revolução socialista na Alemanha, país que sempre representou, para os bolcheviques, o modelo identitário ambivalente por excelência, esse sonho soçobrou no armistício e no acordo de paz que os Russos foram obrigados a assinar com os Polacos (Service, 1995: 118-121, 126-27, 136-139).
} 
cada vez mais perto das concepções de Roy, o desvio leniniano para o Oriente permitia fugir a uma contradição entre a teoria do imperialismo - segundo a qual a globalização do capital trazia a erosão aos Estados-Nação - e a defesa do direito à autodeterminação, apenas justificável se as nações ainda tivessem algum futuro. Ao recolocar nas colónias das metrópoles capitalistas a questão do nacionalismo, Lénine demonstrava que a autodeterminação, ligada aos movimentos de libertação dos povos colonizados, podia ser articulada com a luta contra o imperialismo (Pipes, 1957: 48-9). Tudo se encaixava.

Tal deslocação de ênfase retirava qualquer linearidade às construções identitárias. Se a "Ásia" era o "atraso" da Rússia e o "Ocidente" o seu "progresso", a todo o momento esta polaridade podia ser invertida, passando o "Ocidente" a representar o "atraso" e a "Ásia" o "avanço", sem que essa oscilação se resolvesse pela adesão definitiva a uma dessas representações polarizadas. Nas suas reflexões quase testamentárias, Lénine fez a síntese desta indecidibilidade: uma Rússia de fronteira, situada entre os "Estados imperialistas prósperos do Ocidente" e os "Estados imperialistas prósperos do Oriente", ao mesmo tempo alinhada ao lado da Índia e da China, pertencendo assim, de corpo inteiro, ao bloco maioritário da população mundial e partilhando com ele os traços "progressistas" de quem integra o "Oriente revolucionário" - oposto ao "Ocidente imperialista contra-revolucionário" e os traços "atrasados" daqueles a quem "falta civilização". Eminentemente paradoxal, o devir "asiático" da Rússia revolucionária era a condição para que ela superasse/enfrentasse um atraso não menos "asiático":

O desenlace na luta depende, em última análise, do facto de que a Rússia, a Índia, a China, etc., constituem a gigantesca maioria da população. E é precisamente esta maioria da população que, nos últimos anos, se integra com inusitada rapidez na luta pela sua libertação, de modo que, neste sentido, não pode haver sombra de dúvida em relação a qual será o desenlace definitivo da luta mundial. Neste sentido, a vitória definitiva do socialismo está plena e absolutamente assegurada.

[...] A fim de assegurar a nossa existência até ao próximo choque militar entre o Ocidente imperialista contra-revolucionário e o Oriente revolucionário e nacionalista, entre os Estados mais civilizados do mundo e os Estados atrasados à maneira oriental, os quais, não obstante, constituem a maioria, é preciso que esta maioria se consiga civilizar. A nós, também nos falta civilização para passar directamente ao socialismo, embora tenhamos para isso as premissas políticas. (Lénine, 1979: 680)

A verdade é que, no fim da sua vida, o líder dos bolcheviques teve de assistir à erosão de todas as premissas que, antes, poderiam ter fundamen- 
tado um paradigma de acção à escala mundial: o desenvolvimento do Oriente tinha-se orientado "definitivamente para a via geral do capitalismo europeu”, inviabilizando a utopia de uma transição directa para o comunismo, e, por outro lado, a Alemanha, "país de desenvolvimento realmente avançado e culto", antiga esperança da revolução mundial, estava de tal maneira constrangida pelas imposições do Tratado de Versalhes que se via "agora em grandes dificuldades para se reerguer" (Lénine, 1979: 679). ${ }^{16}$ As expectativas cristalizaram-se, por fim, em torno dessas "centenas de milhões de homens levados ao último grau da miséria humana" que compunham o Oriente. Mas mesmo isso estava ameaçado, a julgar pelo fracasso do Primeiro Congresso dos Povos Oprimidos, efectuado em Baku, ${ }^{17}$ e pela defecção de figuras como Sultan Galiev. ${ }^{18}$

Que todas estas opções estratégicas continuavam, subterraneamente, a travar uma batalha identitária dentro de uma indecidibilidade muito "russa" é o que podemos constatar quando verificamos que, no início dos anos 20 ,

\footnotetext{
${ }^{16}$ Apesar da ênfase no relacionamento com o Oriente, não devemos esquecer que a estratégia internacional de Lénine continuou a mover-se em vários tabuleiros. Assim, o combate ao Tratado de Versalhes tornou-se uma das suas obsessões. De modo a concretizá-la, enveredou por uma Realpolitik que deixou muita gente perplexa. Para estupefacção dos seus camaradas alemães da “Terceira Internacional”, Lénine advogou uma aliança entre os comunistas da Alemanha e os ex-militares de extrema-direita com vista a combater os Aliados e o Tratado de Versalhes, numa lógica de guerra de libertação nacional - isto é, aplicando à Alemanha a receita proposta para os países colonizados que consistia em aliar os comunistas a organizações "burguesas". Um tal pacto anti-natural duraria o tempo necessário para obter a vitória na referida luta. Posteriormente, os comunistas e o proletariado alemães deveriam retomar a sua ofensiva contra a burguesia (Service, 1995: 136). Este raciocínio, puramente táctico, mas, ao mesmo tempo, conformado com os realinhamentos sociopolíticos do pós-guerra, explica-se pela centralidade que Lénine conferia ao Tratado de Versalhes, enquanto "paradigma" da nova ordem política internacional. Um "paradigma" cuja insustentabilidade nem por isso tornava menos urgente combatê-lo, mesmo que para tal fosse necessária uma aliança com o "inimigo de classe". Sobre a importância da "Paz de Versalhes" nas considerações estratégicas e tácticas de Lénine, veja-se o seu "Relatório sobre a Situação Internacional e as Tarefas Fundamentais da Internacional Comunista", apresentado a 19 de Julho de 1920 no Segundo Congresso da Internacional Comunista (Lénine, 1979: 368-375), e o seu discurso secreto na Nona Conferência de Toda a Rússia do Partido Comunista (Pipes, 1996: 101 e 111). ${ }_{17}$ Esse congresso, a que assistiram mil oitocentos e noventa e um delegados oriundos da Turquia, da Pérsia, da China, da Ásia Central, do Cáucaso, etc., explicitou o desentendimento entre os bolcheviques, apegados à ideia de subordinar os movimentos de libertação no Oriente aos interesses da revolução proletária mundial, e os revolucionários nacionalistas, cuja agenda não coincidia de todo com semelhante projecto (Carrère d'Encausse, 2000: 480-4).

${ }^{18} \mathrm{O}$ trajecto de Sultan Galiev é interessante a vários títulos. A partir de certa altura, este tártaro muçulmano, que havia aderido ao comunismo, começou a suspeitar que a revolução proletária mundial não se iria traduzir em emancipação dos povos colonizados e semi-colonizados do Oriente. De 1919 em diante, fortaleceu a convicção de que o proletariado ocidental, mesmo tomando o poder nos seus respectivos países, veria vantagens em preservar as colónias e as condições de exploração dos povos orientais (Pipes, 1957: 261). Galiev chegou mesmo a defender, como base para a emancipação da humanidade, a ideia espantosa de substituir a ditadura mundial do proletariado pela "ditadura das colónias e semi-colónias sobre as metrópoles" (apud Pipes, 1957: 261). Sobre esta figura, ver Bennigsen e Lemercier-Quelquejay, 1986.
} 
Lénine não deixou de procurar uma reabilitação da Rússia enquanto centro da revolução, numa tentativa inequívoca de compensar a representação semiperiférica desse país. A partir dessa altura, o líder do Partido Bolchevique insistiu em exibir a experiência revolucionária soviética como um modelo universal (ou universalizável), a ser estudado pelos restantes movimentos comunistas. Inverteu, assim, a relação de dependência, durante tanto tempo afirmada, entre a revolução russa e a putativa revolução europeia, e redistribuiu, uma vez mais, as posições do centro e da periferia: a Rússia passava agora a ser o centro inspirador da revolução mundial, ideia que a Internacional Comunista haveria de consagrar (Harding, 1981: 236-43). A Rússia tornara-se modelar, não unicamente num sentido "fraco", de exemplo a seguir, mas num sentido "forte", histórico e estrutural: Lénine acreditava, ainda em 1920, que os países da Europa Ocidental expostos a situações revolucionárias, sobretudo a Alemanha, iriam reproduzir todas as etapas, e até mesmo as personagens, da Revolução Russa de 1917. Desse modo, haveria um Kerenski alemão, um Kornilov alemão, umas "jornadas de Julho" alemãs, etc. Conforme Marcel Liebman observou, "apenas" um pormenor estragava estas belas simetrias: "Se a Alemanha teve, no Outono de 1918, o seu 'Fevereiro espontâneo', nunca conheceu o seu Outubro vitorioso” (1973: 297). Mas não era um detalhe como esse que faria recuar o narcisismo revolucionário dos bolcheviques. Na vontade de "paradigmatizar" a experiência local da Rússia soviética, o céu era o limite. Uma Declaração, da autoria de Kliutchnikov e Sabanine, aprovada no Primeiro Congresso dos Sovietes da URSS, afirmava, justamente, que "a união serve como verdadeiro baluarte contra o capitalismo mundial" e que "será um passo novo e decisivo no caminho para a unificação dos trabalhadores de todos os países numa República Socialista Soviética Mundial" (Eudin e North, 1957: 60). Globalizando-se um localismo, a união das Repúblicas russas seria o paradigma da união universal dos povos, tal como o "russo" dos eslavófilos e de Dostoiévski deveria realizar a fraternidade universal, tudo isto temperado por uma forte "imaginação do centro" (para usar uma expressão de Sousa Santos).

Amantes das simbologias e dos cerimoniais, os bolcheviques não perderam oportunidades de encenar ritualmente esta nova posição identitária da Rússia. No dia 19 de Julho de 1920, por ocasião do Segundo Congresso da Internacional Comunista, realizou-se em Petrogrado um espectáculo de massas cujo momento apoteótico estava planeado da seguinte maneira:

Uma salva de canhão anuncia a ruptura do bloqueio da Rússia Soviética e a vitória do proletariado mundial. O Exército Vermelho regressa e os dirigentes revolucionários passam-lhe revista numa marcha cerimonial. Coroas reais são espalhadas aos 
seus pés. Passam navios festivamente decorados, transportando o proletariado ocidental. Operários de todo o mundo, segurando emblemas laborais, precipitam-se para a celebração da Comuna Mundial. No céu cintilam saudações ao Congresso em várias línguas: "Viva a Terceira Internacional", "Proletários de todo o mundo, uni-vos”. // Uma celebração pública triunfal, acompanhada pelo hino da Comuna Mundial, a "Internacional". (von Geldern e Stites, 1995: 32)

Regresso dos mitos profundos de uma cultura: a "Terceira Internacional” casava-se, assim, com o mito escatológico da "Moscovo-Terceira Roma" (Heller e Niquex, 1995: 24). ${ }^{19}$ Um eslavofilismo em versão leninista? Nem tanto. Pois, ambivalentemente, a "humildade nacional" sempre acompanhou, em paralelo, as tentativas leninianas de "paradigmatizar" a revolução russa e as suas formas de poder (Liebman 1973: 298-300). Em Março de 1919, perante o Oitavo Congresso do Partido Comunista da Rússia, Lénine refreara o delírio identitário das hostes bolcheviques, num passo famoso que os comentadores gostam de citar e que contradiz, flagrantemente, qualquer intuito de universalizar as "lições de Outubro" (Harding, 1981: 236):

Seria ridículo apresentar a nossa revolução como um ideal para todos os países, imaginar que ela fez toda uma série de descobertas geniais e introduziu um montão de inovações socialistas. Nunca ouvi ninguém dizê-lo e afirmo que nunca ouviremos ninguém. Temos a experiência prática da realização dos primeiros passos para destruir o capitalismo num país em que existe uma relação particular entre o proletariado e o campesinato. Nada mais. Se imitarmos a rã, bufando e inchando, faremos rir todo o mundo, seremos uns simples fanfarrões. (Lénine, 1979: 111)

Quanto a esse famoso texto, $A$ doença infantil do "esquerdismo" no comunismo, onde o autor atribuía à Revolução Russa uma importância translocal e uma "influência sobre todos os países", ele negava aí, ao mesmo tempo,

\footnotetext{
${ }_{19}$ A ideia de Moscovo enquanto "nova Constantinopla" ou "Terceira Roma" surgiu na Rússia após a tomada de Constantinopla pelos Turcos em 1453, e foi formulada mais especificamente nos anos 20 do século XVI por Filoteu, monge de Pskov, em diversas epístolas dirigidas aos czares Vassili III e Ivan IV. A subtracção de Constantinopla ao universo cristão foi acompanhada, de perto, por outro evento de sinal oposto: a libertação dos Russos em relação ao poder dos Tártaros, no ano de 1480. A conjugação destes dois acontecimentos deixou a cristandade ortodoxa praticamente reduzida à Rússia. Para alguns sábios russos do século XVI, retomando sugestões em crónicas e escritos teológicos mais antigos, Moscovo vinha substituir o lugar outrora ocupado por Constantinopla - cuja queda para eles se justificara dada a cedência à Igreja Latina que os gregos ortodoxos tinham decidido fazer em matéria doutrinal. Doravante, Moscovo formaria uma "Terceira Roma”, imaculada e definitiva, pois nenhuma outra se lhe seguiria. Esta ideia insere-se, naturalmente, na longa duração do messianismo e do escatologismo russos (Lotman e Uspenskij, 1984: 54-56; Averintsev, 1991: 18-20).
} 
a "inevitabilidade histórica da repetição à escala internacional daquilo que aconteceu no nosso país”. E acrescentava: “Seria [...] errado perder de vista que, depois da vitória da revolução proletária, ainda que apenas num dos países avançados, começará por certo uma mudança brusca, a saber: a Rússia deixará logo depois disto de ser um país modelo, e será outra vez atrasado (no sentido "soviético" e socialista)." (Lénine, 1979: 279)

Precisão importante: o carácter modelar da Rússia é provisório, tanto quanto o seu "atraso" é relativo. Pode ser "atrasada" em comparação com os países europeus, no plano cultural e económico, mas ser "avançada" no plano político, ou revelar-se "atrasada" nas duas vertentes se um país economicamente avançado fizer, com eficácia, uma revolução proletária.

Em tudo isto, o referente identitário positivo, se não mesmo ideal, continuava a ser a Europa. Por isso, mais à frente, Lénine reconhecia ter sido "fácil à Rússia começar a revolução socialista, mas continuá-la e levá-la a cabo será mais difícil à Rússia do que aos países europeus" (nos quais, notese, Lénine parecia não incluir a pátria dos sovietes). Entretanto, mais um paradoxo: as massas trabalhadoras da Europa Ocidental eram, afinal, muito menos "avançadas" - imbuídas como estavam de "preconceitos democrático-burgueses e parlamentares" - do que as do país responsável pelos sovietes. Daí que, no Ocidente, a hora fosse de parlamentarismo e não de revolução. Lénine sentia-se, pois, autorizado a desenterrar um texto antigo de Kautsky para argumentar que o centro revolucionário estava a deslocar-se do Ocidente para o Oriente, um "Oriente" simplesmente assimilado ao espaço identitário dos eslavos (Lénine, 1979: 280).

Num mesmo texto, o líder e teórico do bolchevismo podia percorrer assim todo o espectro de recursos estratégicos que o imaginário de fronteira lhe proporcionava. Sem, no entanto, aderir definitivamente a qualquer deles.

\section{Conclusão}

As oscilações que fomos recenseando ao longo deste texto remetem, segundo creio, para a integração de Lénine numa cultura de indecidibilidade identitária. Quando lhe foi necessário pensar o impacto internacional da Rússia, os quadros interpretativos disponíveis mostraram-se profundamente afectados por essa cultura. "Ocidentalista" desconfiado e ressentido em relação ao Ocidente, "orientalista” mais por necessidade do que por convicção, representando a Rússia em tonalidades que podiam ir do depressivo-melancólico ao eufórico e proto-messiânico, estas tensões, ambiguidades e contradições pertencem ao todo das ideias políticas de Lénine, as quais, não poucas vezes, reflectiram em simultâneo todos esses sentimentos. 
Tais ambivalências vieram minar a coerência interna do pensamento leniniano, tornando difícil a tarefa de quem queria encontrar nele um "guia de acção" totalizante para o longo prazo. A "paradigmatização" do "leninismo" só foi realizada a posteriori è custa de imensa rasura, simplificação e compressão dos textos canónicos. Na verdade, estes foram muito mais um "guia" de dilemas e de controvérsias para os companheiros de Lénine que lhe sobreviveram: uma via ocidental-europeia ou uma via oriental e "terceiro-mundista" para a revolução proletária mundial? Dependência da União Soviética relativamente à vitória do socialismo nos países "avançados" ou possibilidade de construir o socialismo "num só país"? Transição acelerada e radical para o comunismo ou compromisso e gradualismo da Nova Política Económica? Não há, em Lénine, uma resposta final que atalhe decididamente por um dos termos de cada um destes binómios ou que faça a síntese (impossível?) de todas as alternativas.

Auto-representando-se ambivalentemente na fronteira entre a Europa e a Ásia, entre o Ocidente e o Oriente, a cultura identitária que subjaz ao pensamento político de Lénine e dos seus seguidores foi, portanto, decisiva nas opções que decidiram a Revolução de Outubro e muito do que se lhe seguiu. Por um lado, uma imagem masoquisticamente menorizada da Rússia, em contraste com uma Europa distante e desejada; por outro, um messianismo megalómano pelo qual a Rússia rejeita a Europa que a periferiza e se coloca no centro do mundo asiático, com uma missão redentora de escala mundial. São estes os dois pólos imaginários, igualmente desproporcionados e igualmente delirantes, entre os quais tem oscilado a identidade de fronteira da cultura russa, numa constância que se diria estrutural e que suscita a nossa interrogação, para esclarecer o ontem, mas também o hoje. As tentativas actuais de descobrir uma identidade para a Rússia não cessam, portanto, de reutilizar as pedras de um edifício arcaico que ninguém parece verdadeiramente interessado em desconstruir ou simplesmente abandonar. ${ }^{20}$

\footnotetext{
${ }^{20}$ Sintoma desse "passado que não quer passar" é o projecto identitário em que Vladimir Putine tem insistido publicamente, projecto que consiste em resgatar uma "ideologia nacional" para a Rússia - conceito tão vago quanto volátil -, a qual acaba por reincarnar no velho patriotismo eslavófilo, com algumas consequências práticas em termos políticos, das quais se destaca o projecto de reunificação das regiões "eslavas" da ex-União Soviética, particularmente da Rússia com a Bielorrússia (Larina, 1999; Rosenberger, 2001; Zolotov Jr., 2002; Sørlie, 2003). Alguns inquéritos realizados pelo VTsIOM - um instituto de sondagens anteriormente dirigido pelo sociólogo Iuri Levada, que, apesar de pertencer ao Estado russo, conseguiu manter a sua independência até 2003, ano em que passou a ser controlado directamente por instâncias governamentais - e citados por Afanassiev (2002: 397), são bastante reveladores no que toca à influência do tradicionalismo eslavófilo sobre a mentalidade do cidadão comum. Assim, em 2000, 86\% de 1580 pessoas inquiridas na Rússia consideravam que "o homem russo demonstra uma alma particularmente calorosa, desconhecida do europeu", $70 \%$ entendiam que "apenas o russo consegue sacrificar-se em nome de
} 
Não admira, assim, que os estrategos que ponderam hoje as alianças a estabelecer para a Rússia pós-soviética continuem a debater-se com o mesmo dilema identitário que fomos encontrando ao longo da nossa análise:

[...] Para a forma como o mundo se está a desenvolver, faz diferença saber onde a Rússia, proclamada por muitos analistas ocidentais como um "Estado de terceira classe", estará no sistema internacional e com quem se irá aliar, e se a Rússia será um país "europeu” na Ásia ou um país "asiático" na Europa. (Voskressenski, 1999: 62)

Este "retorno do mesmo" não explica todo o insucesso da promessa revolucionária de 1917, como também não explica a transição do falso socialismo de ontem para o falso capitalismo de hoje. Não tenciono, pois, suscitar aqui uma espécie de determinismo identitário - em alternativa aos determinismos mais comuns, de cariz historicista, sociologista ou economicista - que atribuiria aos processos de construção das identidades nacionais uma qualquer primazia na determinação das trajectórias históricas. Contudo, se apenas a "constelação de determinações" representa uma base epistemologicamente válida para as explicações causais (Louçã, 1997: 38), há que incorporar os processos identitários no modelo explicativo global, sob pena de descurarmos uma condicionante fundamental da acção humana, precisamente aquela que decorre das imagens que os sujeitos constroem de si e dos outros. Imagens eminentemente poderosas, impregnadas pelos afectos de amor e de ódio, e nas quais o sujeito investe o seu próprio destino narcísico, de orgulho ou de humilhação identitária. Imagens, enfim, que também servem de armas de arremesso contra os "outros", quando representadas como pólos negativos de que o sujeito se diferencia para melhor se afirmar (Volkan, 1988). Imagens que são, por isso, terreno fértil para conflitos que revestem a forma, tantas vezes insuspeita, de "guerras identitárias" (Volkan, 1997, 2006).

O entendimento da Revolução soviética talvez ganhe uma nova luz se nele introduzirmos o factor das identidades e, em particular, dos processos que levaram à construção da identidade nacional, colando à Rússia suces-

um grande fim", $71 \%$ pensavam que "a Rússia se distingue por uma natureza própria e uma cultura espiritual superiores a todos os outros países”, e 79\% por cento estavam convencidos de que “a Rússia é um grande país que só se pode compreender se acreditarmos na sua predestinação". Acrescente-se, por último, o dado especialmente significativo de $72 \%$ dos inquiridos concordarem com a ideia de que "o homem russo não pode dispensar dirigentes capazes de comandar, de uma mão de ferro que oriente as suas acções”. Ainda mais recentemente, uma outra sondagem realizada pelo instituto de Levada, em Junho de 2005, sugere que os sentimentos eslavófilos e grão-russos da população exibem uma cada vez maior xenofobia: $58 \%$ dos inquiridos reconheciam-se no slogan de "A Rússia para os russos" (Clément e Paillard, 2005: 18). 
sivos e contraditórios rostos. Esta perspectiva ajuda-nos, desde logo, a perceber que as estratégias políticas são também estratégias identitárias, e que, por exemplo, ao tomarem certas decisões no sentido de inflectir as trajectórias sociais, os bolcheviques manipularam estrategicamente símbolos e imagens da "nação russa" de forma a extrair deles efeitos legitimadores. A própria indecidibilidade identitária atribuída à Rússia ajudou Lénine e os seus companheiros a flexibilizar as opções estratégicas e a não se comprometerem com cenários geopolíticos de teor definitivo.

Por outro lado, sendo as identidades sociais o tipo acabado de fenómenos em que a longa duração resiste à mudança, a análise das persistências identitárias talvez permita compreender uma parte importante daquilo que tem minado ou corroído as transições societais num país como a Rússia, reduzidas a transições entre o mesmo e o mesmo (a falsas transições, por conseguinte) ou, na melhor das hipóteses, a transições entre uma impossibilidade e um mal-entendido, entre modelos cuja validade há muito se esgotara e alternativas cujas virtualidades se revelam intrinsecamente ilusórias, ou tão susceptíveis de sofrer distorções no seu percurso que depressa perdem credibilidade. Em grande medida, também a história da Revolução Russa não pode senão jogar-se nesta nostalgia de um futuro que teima em não acontecer.

\section{Referências bibliográficas}

Afanassiev, Iuri (2002), De la Russie. Les enjeux actuels. Paris: Fayard.

Anderson, Perry (1979), Lineages of the Absolutist State. London/New York: Verso. Ascher, Abraham (1972), Pavel Axelrod and the Development of Menshevism. Cambridge, MA: Harvard UP.

Averintsev, Sergei (1991), "The Idea of Holy Russia”, in Paul Dukes (org.), Russia and Europe. London: Collins and Brown, 10-23.

Bhabha, Homi (1994), The Location of Culture. London/New York: Routledge.

Barth, Fredrik (1998), "Introduction", in Fredrik Barth (org.), Ethnic Groups and Boundaries: The Social Organization of Culture Difference. Illinois: Waveland Press, 9-38.

Bastos, José Gabriel Pereira (1995), "Portugal, minha Princesa": Contribuição para uma antropologia pós-racionalista dos processos identitários e para o estudo do sistema de representações sociais identitárias dos Portugueses. Lisboa: Faculdade de Ciências Sociais e Humanas da Universidade Nova (diss. de Doutoramento em Antropologia Social e Cultural).

Bastos, José Gabriel Pereira (2000), Portugal europeu. Estratégias identitárias inter-nacionais dos Portugueses. Lisboa: Celta. 
Bennigsen, Alexandre; Lemercier-Quelquejay, Chantal (1986), Sultan Galiev: Le père de la révolution tiers-mondiste. Paris: Fayard.

Berlin, Isaiah (1994), Russian Thinkers. London: Penguin Books.

Braudel, Fernand (s.d.), Civilização material, economia e capitalismo, séculos XV-XVIII. Tomo 3: O tempo do mundo. Trad. Telma Costa. Lisboa: Teorema.

Brovkin, Vladimir (1987), The Mensheviks after October: Socialist Opposition and the Rise of the Bolshevik Dictatorship. Ithaca/London: Cornell UP.

Burbank, Jane (1986), Intelligentsia and Revolution: Russian Views of Bolshevism, 1917-1922. New York/Oxford: Oxford UP.

Carr, Edward Hallett (1966), The Bolshevik Revolution, 1917-1923. New York: Penguin Books.

Carrère d'Encausse, Hélène (1987), Le grand défi. Bolcheviks et nations 1917-1930. Paris: Flammarion.

Carrère d'Encausse, Hélène (2000), Lénine. Paris: Hachette Littératures.

Clément, Carine; Paillard, Denis (2005), "Dix éclairages sur la société russe”, Monde Diplomatique, Novembro, 18-19.

Daniels, Robert Vincent (1960), The Conscience of the Revolution: Communist Opposition in Soviet Russia. Cambridge, MA/London: Harvard UP/Oxford UP.

Daniels, Robert Vincent (org.) (1987), A Documentary History of Communism. Vol. 2: Communism and the World. London: I. B. Tauris \& Co.

Dobb, Maurice (1948), Soviet Economic Development since 1917. New York: International Publishers.

Erikson, Erik (1994), Identity: Youth and Crisis. New York/London: W. W. Norton \& Company.

Eudin, Xenia Joukoff; North, Robert (orgs.) (1957), Soviet Russia and the East 1920-1927: A Documentary Survey. Stanford, CA: Stanford UP.

Figes, Orlando (2003), Natasha's Dance: A Cultural History of Russia. London: Penguin Books.

Fitzpatrick, Sheila (1991), "The Problem of Class Identity in NEP Society”, in Sheila Fitzpatrick; Alexander Rabinowitch; Richard Stites (orgs.), Russia in the Era of NEP: Explorations in Soviet Society and Culture. Bloomington/Indianapolis: Indiana UP, 12-33.

Fitzpatrick, Sheila (1993), “Ascribing Class: The Construction of Social Identity in Soviet Russia”, Journal of Modern History, 65(4), 745-770.

Galili, Ziva (1989), The Menshevik Leaders in the Russian Revolution: Social Realities and Political Strategies. Princeton: Princeton UP.

Geldern, James von; Stites, Richard (orgs.) (1995), Mass Culture in Soviet Russia: Tales, Poems, Songs, Movies, Plays, and Folklore, 1917-1953. Bloomington: Indiana UP. Getzler, Israel (1967), Martov: A Political Biography of a Russian Social Democrat. Australia/New Zealand: Cambridge UP/Melbourne UP. 
Gilroy, Paul (1996), The Black Atlantic: Modernity and Double Consciousness. London/ New York: Verso.

Haimson, Leopold (1966), The Russian Marxists and the Origins of Bolshevism. Boston: Beacon Press.

Haimson, Leopold (org.) (1974), The Mensheviks from the Revolution of 1917 to the Second World War. Chicago/London: The University of Chicago Press.

Halperin, Charles (1982), "George Vernadsky, Eurasianism, the Mongols, and Russia”, Slavic Review, 41(3), 477-493.

Hall, Stuart; Gay, Paul du (orgs.) (1996), Questions of Cultural Identity. London: Sage.

Hardeman, Hilde (1994), Coming to Terms with the Soviet Regime: The "Changing Signposts" Movement among Russian Emigrés in the Early 1920s. DeKalb: Northern Illinois UP.

Harding, Neil (1981), Lenin's Political Thought. Vol. 2: Theory and Practice in the Socialist Revolution. New York: St. Martin's Press.

Heller, Leonid; Niqueux, Michel (1995), Histoire de l'utopie en Russie. Paris: PUF. Hosking, Geoffrey (2003), Russia and the Russians: A History. Cambridge, MA: The Belknap Press of Harvard University Press.

Kowalski, Ronald (1991), The Bolshevik Party in Conflict: The Left Communist Opposition of 1918. Pittsburgh: University of Pittsburgh Press.

Larina, Ekaterina (1999), "National Idea Back on Russia's Agenda”, The Russia Journal Society (http://www.therussiajournal.com/index.htm?obj=1871, acedido em 31 de Maio de 2004).

Lénine (1963-1965), Collected Works. Moscow: Progress Publishers.

Lénine (1978), Obras escolbidas, Tomo 2. Lisboa/Moscovo: Avante! /Progresso.

Lénine (1979), Obras escolbidas, Tomo 3. Lisboa/Moscovo: Avante! /Progresso.

Lewin, Moshe (1969), Lenin's Last Struggle. London: Faber and Faber.

Liebman, Marcel (1973), Le léninisme sous Lénine: 2. L'épreuve du pouvoir. Paris: Seuil. Louçã, Francisco (1997), Turbulência na economia - Uma abordagem evolucionista dos ciclos e da complexidade em processos históricos. Porto: Afrontamento.

Lotman, Iuri; Uspenskij, Boris (1984), The Semiotics of Russian Culture. Ann Arbor: University of Michigan Press.

Laplanche, Jean; Pontalis, Jean-Bertrand (1985), Vocabulário de psicanálise. Lisboa: Moraes.

Machaqueiro, Mário (2007), "Frontier Identity in Portugal and Russia: A Comparative Perspective on Identity Building in Semiperipheral Societies" (no prelo).

Meijer, Jan (org.) (1964), The Trotsky Papers, 1917-1922. I: 1917-1919. London/The Hague/Paris: Mouton \& Co.

Melançon, Michael; Pate, Alice (orgs.) (2002), New Labor History: Worker Identity and Experience in Russia, 1840-1918. Bloomington: Slavica. 
Morley, David; Chen, Kaun-Hsing (orgs.) (1996), Stuart Hall - Critical Dialogues in Cultural Studies. London/New York: Routledge.

Nahirny, Vladimir (1983), The Russian Intelligentsia: From Torment to Silence. New Brunsvick/London: Transaction Books.

Pipes, Richard (1957), The Formation of the Soviet Union: Communism and Nationalism, 1917-1923. Cambridge, MA: Harvard UP.

Pipes, Richard (org.) (1961), The Russian Intelligentsia. New York: Columbia UP.

Pipes, Richard (org.) (1996), The Unknown Lenin: From the Secret Archive. New Haven/ London: Yale UP.

Pomper, Philip (1970), The Russian Revolutionary Intelligentsia. New York: Thomas Y. Crowell Company.

Rosenberger, Chandler (2001), "National Unity and the Russian Idea”, Comunicação apresentada na Universidade de Columbia a 6 de Abril de 2001, no painel "Putin's Russia and the Pursuit of Derzhavnost", integrado na conferência anual da Association for the Study of Nationalities (http://people.bu.edu/crr/Putin.htm, acedido em 1 de Junho de 2004).

Santos, Boaventura de Sousa (1994), Pela mão de Alice. O social e o político na pós-modernidade. Porto: Afrontamento.

Santos, Boaventura de Sousa (2002), "Entre Prospero e Caliban: Colonialismo, pós-colonialismo e inter-identidade”, in Maria Irene Ramalho; António Sousa Ribeiro (orgs.), Entre Ser e Estar. Raízes, percursos e discursos da identidade. Porto: Afrontamento, 23-85.

Service, Robert (1991), Lenin: A Political Life. Vol. 2: Worlds in Collision. Bloomington: Indiana UP.

Service, Robert (1995), Lenin: A Political Life. Vol. 3: The Iron Ring. Bloomington: Indiana UP.

Siegelbaum, Lewis H.; Suny, Ronald Grigor (orgs.) (1994), Making Workers Soviet: Power, Class and Identity. Ithaca/London: Cornell UP.

Shlapentokh, Dmitry (1997), "Eurasianism: Past and Present", Communist and Post-Communist Studies, 30(2), 129-151.

Smith, Anthony (1991), National Identity. Reno/Las Vegas/London: University of Nevada Press.

Sørlie, Tor Jostein (2003), "Pan-Slavism - Past and Present", Europe in the World (http://www.svj.hvu.nl:8081/eitw/stories/storyReader\$184, acedido em 31 de Maio de 2004).

Steinberg, Mark (2001), Voices of Revolution. New Haven/London: Yale UP.

Suny, Ronald Grigor (1993), The Revenge of the Past: Nationalism, Revolution, and the Collapse of the Soviet Union. Stanford: Stanford UP.

Taibo, Carlos (1999), La Unión Soviética: El espacio ruso-soviético en el siglo XX. Madrid: Editorial Síntesis. 
Trubetskoi, Nikolai Sergeevitch (1991), The Legacy of Genghis Khan and Other Essays on Russia's Identity. Ann Arbor: Michigan Slavic Publications.

Volkan, Vamik (1988), The Need to Have Enemies and Allies: From Clinical Practice to International Relationships. Northvale/New Jersey/London: Jason Aronson.

Volkan, Vamik (1997), Bloodlines: From Ethnic Pride to Ethnic Terrorism. Boulder: Westview Press.

Volkan, Vamik (2006), Killing in the Name of Identity: A Study of Bloody Conflicts. Charlottesville: Pitchstone Publishing.

Voskressenski, Alexei (1999), “The Russian Grand Strategy Towards China”, Current Politics and Economics of Russia, Eastern and Central Europe, 12(1), 37-63.

Wallerstein, Immanuel (s.d.), O sistema mundial moderno. Vol. I: A agricultura capitalista $e$ as origens da economia-mundo europeia no século XVI. Trad. Carlos Leite, Fátima Martins e Joel de Lisboa. Porto: Afrontamento.

Walicki, Andrzej (1989), The Slavophile Controversy: History of a Conservative Utopia in Nineteenth-Century Russian Thought. Notre Dame: University of Notre Dame Press.

Wallerstein, Immanuel (1979), The Capitalist World-Economy. Cambridge: Cambridge UP/ Paris: Éditions de la Maison des Sciences de l'Homme.

Zolotov Jr, Andrei (2002), "Putin Raises Belarus Stakes", The St. Petersburg Times (http://www.sptimes.ru/archive/times/795/top/t_7161.htm, acedido em 1 de Junho de 2004). 